\title{
Health-related quality of life profile of Indonesian children and its determinants: a community-based study
}

\author{
Mei Neni Sitaresmi ${ }^{*}$, Braghmandita Widya Indraswari ${ }^{1}$, Nisrina Maulida Rozanti ${ }^{2}$, Zena Sabilatuttaqiyya ${ }^{2}$ and \\ Abdul Wahab ${ }^{3}$
}

\begin{abstract}
Background: Assessing health-related quality of life (HRQOL) and its determinants in children may provide a comprehensive view of child health. The study aimed to assess the HRQOL in Indonesian children and its determinants.

Methods: We conducted a community-based cross-sectional study in the Sleman District of Yogyakarta Special Province, Indonesia, from August to November 2019. We recruited children aged 2 to 18 years old using the Sleman Health and Demography Surveillance System sample frame. We used the validated Indonesian version of Pediatric Quality of life Inventory ${ }^{\mathrm{TM}}$ (Peds QL ${ }^{\mathrm{TM}}$ ) 4.0 Generic core scale, proxy-reports, and self-reports, to assess the HRQOL.

Results: We recruited 633 proxies and 531 children aged 2-18years. The mean total score of self-report and proxyreport were $89.9 \pm 8.5$ and $93.3 \pm 6.4$. There was a fair to moderate correlation between self-reports and proxy-reports, with intra-class correlation ranging from 0.34 to 0.47 , all $p<0.001$. Half of the children ( $49.4 \%$ from proxy-report and $50.1 \%$ from self-report) reported having acute illness during the last month. Based on proxy-reports, multivariate regression analysis demonstrated lower HRQOL for children with acute health problems, younger age, history of low birth weight, abnormal delivery, lower fathers' educational level, and government-paid insurance for low-income families.

Conclusion: Sociodemographic determinants of a child's $\mathrm{HRQOL}$, acute health problems, and low birth weight were associated with lower HRQOL in the general pediatric population. In low- and middle-income countries where acute infections and low birth weight are still prevalent, its prevention and appropriate interventions should improve child health.
\end{abstract}

Keywords: Health-related quality of life, Children, Acute illness, Sociodemographic, Low- and middle-income countries

\section{Background}

Health-related quality of life (HRQOL) can give a broader aspect of health according to the World Health Organization (WHO) constitution, including aspects of perceived

\footnotetext{
*Correspondence: msitaresmi@ugm.ac.id

1 Department of Child Health, Faculty of Medicine, Public Health and Nursing, Universitas Gadjah Mada (UGM)/ RSUP DR Sardjito, Jalan Farmako Sekip Utara, Yogyakarta 55281, Indonesia

Full list of author information is available at the end of the article
}

health, psychosocial, mental health, and well-being [1]. Therefore, HRQOL can comprehensively measure child health in the general population and better identify unrecognized conditions, social and emotional problems, and poor functioning [2]. Measuring HRQOL in the pediatric population can help determine the burden of disease and assess the impact of prevention and intervention. Furthermore, it may also identify health disparities, assist in the evaluation of the health care needs of 
a community, and makes a policy decision for stakeholders [3]. Self-assessed health status is also a more powerful predictor of mortality and morbidity than many objective measures of health [4].

Previous studies showed some determinants of HRQOL in children and adolescents, such as sociodemographic factors, gender, age, and health status. Lower parental income and lower parental educational level were associated with lower HRQOL [5]. The number of health problems and health care visits are negatively correlated with HRQOL $[6,7]$. Perinatal factors such as birth weight and gestation age were related to HRQOL in adolescence [8]. In Indonesia, as a low- and middleincome country, the prevalence of acute illness and low birth weight is still high [9]. LBW has been identified as a risk of adverse outcomes, not only infant mortality-morbidity but also impaired neurodevelopment outcomes at school-age and non-communicable diseases later in life. Acute illness and LBW may be associated with low children's HRQOL [10]. Therefore, it is crucial to assess the influence of acute disease and low birth weight on HRQOL. The study aimed to evaluate the HRQOL in children aged 2-18years in the general population and its determinants.

\section{Methods}

\section{Study design}

We conducted a community-based cross-sectional study in the Sleman District of Yogyakarta Special Province, Indonesia. Sleman District, a semi-urban city, consists of 17 sub-districts and 86 villages and is $574.82 \mathrm{~km}^{2}$ wide, with a population of $1,167,481$, and $29.5 \%$ are under 20 years old [11]. We randomly selected 660 children aged 2-18 years old living in the area of Health and Demographic Surveillance System (HDSS), Sleman. The study aimed to evaluate the HRQOL in children in the general population and focused on the correlation between acute conditions with HRQOL. Therefore, we excluded children with chronic health problems and hospitalized children during data collection. All parents of these children who meet the inclusion and exclusion criteria filled the proxy-report PedsQL questionnaire. However, since the self-report PedsQL is only available for children aged 5-18 years old, we only included those children aged 5-18years to fill the self-report PedsQL questionnaire. Considering the total population of children and level of confidence $95 \%$, the sample size was 600 subjects. A cluster sampling approach was used to collect the sample from children in The Health and Demographic Surveillance System (HDSS) sample frame in Sleman, Yogyakarta. The Sleman HDSS is a longitudinal household-based survey, and the survey was conducted annually, starting in 2015 [11]. Ethical approval was obtained from the Medical and Health Research Ethics Committee of the Faculty of Medicine, Public Health, and Nursing.

Written informed consent was obtained from all parents/guardians of the children 2-18years, and assent of 11-18 years old children. Participation was voluntary, and confidentiality was ensured.

\section{Instruments and measurements}

Trained interviewers collected data at a home visit through a Computer-Assisted Personal Interview on a tablet device. The data were transferred to the server through the Internet. The quality control consisted of spot-checks of $5 \%$ of interviews to control adherence to the protocol, re-checks to ensure the validity of the interview, and computer-based data cleaning. Sociodemographic data includes parental data on educational level ( $<9$ years is considered as low education level), working status, living area (urban and rural-based on the listing from the Indonesia statistic), and health insurance ownership (government-paid for low-income families, selffunding for more prosperous families). Children's data included age, gender, birth weight (birth weight $<2500 \mathrm{~g}$ is considered as LBW, mode of delivery, and health condition (if the child suffered from fever, diarrhea, vomiting, cough, and other symptoms during the last month).

HRQOL was assessed using The Indonesian Validated Version of Pediatric Quality of life Inventory ${ }^{\mathrm{TM}}$ (PedsQL $^{\mathrm{TM}}$ ) 4.0 Generic Core Scale. A cultural-linguistic validation test has been conducted by Sitaresmi et al. [12]. The Ped$\mathrm{SQL}^{\mathrm{TM}}$ is a multidimensional instrument developed by Varni et al. [13]. It consists of 23 items categorized into four subscales: physical functioning (8 items), emotional functioning (5 items), social functioning (5 items), and school functioning (5 items). For interpretation, three scores can be obtained: physical health (score of the physical functioning subscale), psychosocial health (combined scores of the emotional functioning, social functioning, and school functioning subscales), and the total score (combined score of physical health and psychosocial health). The PedsQL is available for children aged: $5-7,8-12$, and 13-18years old, as well as for the guardian of children aged: $2-4,5-7,8-12$, and $13-18$ years old. The scale has five Likert response options: never, almost never, sometimes, often, and almost always. To simplify the interpretation, all Likert scales were converted to $0-100$. The higher scores indicate a higher HRQOL. There are only three response options for the versions adapted to children between the ages of 5 and 7 years: never, some- times, and almost always (corresponding to $100,50,0)$. For this age, a Face Scale was used, comprising 3 pictures of facial expressions varying from a smiling face to a very sad face to indicate no problem/difficulty to a lot of problems/difficulty [14]. 


\section{Statistical analysis}

We used EpiData for data management, and data analysis was performed with SPSS version 25 for Windows. Baseline characteristics were first described using mean, median, or proportion as appropriate. Mean presented by calculation of total score of HRQOL for each subject. We compared scores between different demographic characteristics using the Independent-Sample T-Test. To identify variables that most closely predict the HRQOL score, we conducted a backward multiple regression analysis for each PedsQL ${ }^{\mathrm{TM}}$ subscale as the dependent variable and sociodemographic characteristic and health status as an independent variable. Analyses were performed with two-sided tests, and a $p$-value $<0.05$ was considered significant. Agreement between child self-report and parent proxy-report on the Ped$\mathrm{sQL}^{\mathrm{TM}} 4.0$ was assessed using Intra-Class Correlation Coefficients (ICC). An ICC lower than 0.4 was considered as very low, 0.4 to 0.74 as low to acceptable, and 0.75 or higher as excellent [15].

\section{Results}

\section{Participant characteristics}

A total of 633 guardians, most of them were mothers (66\%), and 531 children were recruited. Table 1 shows that slightly more boys $(51.8 \%)$ than girls participated, with the mean age being $10.40 \pm 4.7$ years. Half of the children both from self-report and proxyreport reported suffering from acute illness, with the most common symptoms were cough/coryza (37.8\%), fever (12.5\%), and diarrhea (2.5\%). A higher proportion of 2-12 years old children (56\%) suffered from an acute illness compared to the adolescence group (38\%). Table 2 shows the mean score of self-reports and proxyreports. Both from self-reports and proxy-reports, school functioning, was the lowest score. There was a low to moderate agreement between self-reports and proxy-reports, with ICCs ranging from 0.38 to 0.49 . (Table 2).

\section{Bivariate analysis}

Table 3 shows that the number of children, child position in the family, father educational level, working parents' status, health insurance ownership, and child health status are significantly related to HRQOL based on the self-report. Table 4 shows that child age, birth weight, mode of delivery, father education level, health insurance ownership, and child health status are significantly related to HRQOL based on the proxy report. A higher total mean score was found in children without a history of acute illness during the past last month, history of normal birth weight, normal delivery, higher level of father's education, and self-funding Insurance based on the proxy report. Both children and their guardians did not report any significant gender differences in HRQOL.

\section{Multivariate analysis}

In linear regression models, variables included in the final model for the total mean score of child-report were child health status, number of children, living area, and father education level. Children who suffered from acute illness during the last month, children with lower fathers' education level, and who live in an urban area perceived lower HRQOL than their counterparts. The final regression model for the total mean score for proxy-reports included children's age, health status, birth weight, mode of delivery, fathers' education level, and insurance ownership. The coefficients and corresponding confidence intervals are presented in Table 5.

\section{Discussion}

Measuring HRQOL and its determinants in the pediatric population can provide insight into developing more targeted public health policies planned by multiple stakeholders [16]. To our knowledge, this study was the first study assessing HRQOL and its determinants in the general pediatric population in Indonesia. Surprisingly, the total score of HRQOL in our general pediatric population is higher than those in the references study by Varni et al., $89+9$ vs. $84+12$ (self-reports) and $92+6$ vs. $82+15$ (proxy-reports) [3]. However, the mean total score of our study was similar to the scores from healthy children in India $(87 \pm 11)$ for self-reports and $90 \pm 9$ for proxyreports [17]. According to WHO, quality of life is a personal perception of their position in life in the context of their culture and value system and related to their goals, expectations, values, and concerns [18]. The high score of HRQOL in our study may be explained by the fact that our population positively perceived and was more satisfied with their lives. A study by Jaafar et al. showed that Indonesian adolescents had significantly higher happiness, gratitude, and resilience levels than neighbouring countries [19]. According to a survey conducted by a UKbased charity foundation, Indonesian youths topped the list among the happiest in 20 countries. In addition, the survey reported that Indonesian youths had better emotional wellbeing, less anxiety, and strong religious faith $[20,21]$.

In both self-reports and proxy-reports, the school functioning was the lowest score among the other domains. It may be explained that almost half of our respondents, especially in the age of $2-12$ years, had an acute illness. It may result in school absences and lower the school score. This finding is similar to the study assessing HRQOL of 
Table 1 General Characteristic of Respondents

\begin{tabular}{|c|c|c|}
\hline Variable & $\begin{array}{l}\text { Child self-reports } \\
(n=531) \\
n(\%)\end{array}$ & $\begin{array}{l}\text { Proxy-reports } \\
(n=633) \\
n(\%)\end{array}$ \\
\hline \multicolumn{3}{|l|}{ Respondent status } \\
\hline Fathers & & $143(22.59)$ \\
\hline Mothers & & $420(66.35)$ \\
\hline Other caregivers & & $70(11.06)$ \\
\hline Child age in year, mean (SD) & $11.5(3.9)$ & $10.4(4.7)$ \\
\hline 2-12year-group & $300(56,50)$ & $396(62.56)$ \\
\hline 13-18year-group & $231(43.50)$ & $237(37.44)$ \\
\hline \multicolumn{3}{|l|}{ Child gender } \\
\hline Male & $281(52.92)$ & $328(51.82)$ \\
\hline Female & $250(47.08)$ & $305(48.18)$ \\
\hline \multicolumn{3}{|l|}{ Number of children in the family } \\
\hline 1 & $82(15.44)$ & $111(17.54)$ \\
\hline 2 & $266(50.09)$ & $311(49.13)$ \\
\hline$\geq 3$ & $183(34.46)$ & $211(33.33)$ \\
\hline \multicolumn{3}{|l|}{ Order of the child in the family } \\
\hline 1st child & $231(43.50)$ & $270(42.65)$ \\
\hline 2nd or more & $300(56.50)$ & $363(57.35)$ \\
\hline \multicolumn{3}{|l|}{ Birth weight } \\
\hline$\geq 2500 \mathrm{~g}$ & $480(90.40)$ & $574(90.68)$ \\
\hline$<2500 \mathrm{~g}$ & $30(5.65)$ & $38(6.00)$ \\
\hline Unknown & $21(3.95)$ & $21(3.32)$ \\
\hline \multicolumn{3}{|l|}{ Mode of delivery } \\
\hline Normal & $455(85.69)$ & $528(83.41)$ \\
\hline SC & $75(14.12)$ & $104(16.43)$ \\
\hline Unknown & $1(0.19)$ & $1(0.16)$ \\
\hline \multicolumn{3}{|l|}{ History of illness in the past one month } \\
\hline Yes & $237(44.63)$ & $313(49.45)$ \\
\hline No & $294(55.37)$ & $320(50.55)$ \\
\hline \multicolumn{3}{|l|}{ Location } \\
\hline Urban & $458(86.25)$ & $549(86.73)$ \\
\hline Rural & $73(13.75)$ & $84(13.27)$ \\
\hline \multicolumn{3}{|l|}{ Fathers' educational level } \\
\hline Basic education (< 9years education) & $173(32.58)$ & $195(30.81)$ \\
\hline Higher education ( $\geq 9$ years education) & $358(67.42)$ & $438(69.19)$ \\
\hline \multicolumn{3}{|l|}{ Mothers' educational level } \\
\hline Basic education (<9years education) & $169(31.83)$ & $195(30.81)$ \\
\hline Higher education (>9years education) & $362(68.17)$ & $438(69.19)$ \\
\hline \multicolumn{3}{|l|}{ Working situation parents } \\
\hline both parents work & $245(46.14)$ & $285(45.02)$ \\
\hline one parent work or both parents do not work & $286(53.86)$ & $348(54.98)$ \\
\hline \multicolumn{3}{|l|}{ Insurance } \\
\hline Paid by government or do not have Insurance & $317(59.69)$ & $371(58.61)$ \\
\hline self-funded & $214(40.31)$ & $262(41.39)$ \\
\hline
\end{tabular}


Table 2 Intra-Class Correlation between self-report and proxyreport

\begin{tabular}{lllll}
\hline Scale descriptive & $\begin{array}{l}\text { Child self-reports } \\
\text { Mean (SD) }\end{array}$ & $\begin{array}{l}\text { Proxy-reports } \\
\text { Mean (SD) }\end{array}$ & ICC & $\boldsymbol{p}$ \\
\hline Total sample (n) & 531 & 633 & & \\
Total score & $89.28(8.92)$ & $92.90(6.73)$ & 0.49 & $<0.000$ \\
Physical health & $94.24(7.65)$ & $96.35(6.27)$ & 0.45 & $<0.000$ \\
Psychosocial health & $87.63(10.30)$ & $91.71(8.02)$ & $0.48<0.000$ \\
Emotional function- & $85.19(15.39)$ & $89.24(12.07)$ & $0.41<0.000$ \\
ing & & & & \\
Social functioning & $93.14(10.873)$ & $96.49(7.65)$ & $0.38<0.000$ \\
School functioning & $84.39(13.80)$ & $89.35(11.56)$ & 0.48 & $<0.000$ \\
\hline
\end{tabular}

SD Standard deviation

children with acute febrile illness [16] and in bronchitis children [22], which used the PedsQL ${ }^{\mathrm{TM}}$ and found the school functioning was the lowest score.

\section{Sociodemographic determinant of child HRQOL}

We found some sociodemographic characteristics related to children's HRQOL. Children who were living in the rural area reported better HRQOL than their urban counterparts. This is remarkable, considering the rural area is associated with a low-resource setting. The finding may probably be due to different perceptions or expectations about HRQOL and life amenities between rural and urban children [17]. As reported by a previous study [23], we found that children with a higher father's education level had higher HRQOL, both from the self-reports and proxy-reports. Higher levels of parents' education might increase parents' awareness and knowledge about their children's health and support getting better occupations and income, leading to better HRQOL and life expectancy [23].

On the contrary, we did not find any influence of maternal educational level on children's HRQOL. It may be explained by the fact that fathers still hold the leading role in most of Indonesia's families. Indonesia is using a patriarchal system which is still common in society and generally accepted by the community. This system raises the principle and value that all the family's decisions, including children's education and health-seeking behavior, are managed by the fathers [24].

A previous study found the health insurance ownership influenced a child's HRQOL [25]. We found that children from self-funding insurance families had higher HRQOL scores than children from families with government-paid insurance or no insurance, both from proxyreports as well as self-reports. In our population, health insurance ownership may indirectly reflect family socioeconomic status. Since 2014, the Indonesian government has introduced National Health Insurance. This obligatory national health insurance system combines government-paid health insurance for low-income families and contributory-based (self-funding) health insurance for the more prosperous families [26]. In addition, people with health insurance receive more appropriate and recommended use of health services and have better health outcomes. In contrast, people with no insurance are less likely to receive preventive and screening services, regular and continuing sources of care [27].

Previous study that found declining HRQOL with increasing age [28]. Interestingly, our adolescent group had higher HRQOL than younger children. However, the higher HRQOL in the adolescent group was only in the proxy-report group, which included children aged $2-4$ years. In the self-report group, which consists of children older than 5 years, there was no significant difference in HRQOL between the younger and adolescent groups. It may be related to the higher prevalence of acute disease in younger Indonesia's children, especially under-five [9]. We found a higher proportion of 2-12 years old children (56\%) suffered from an acute illness than the adolescent group (38\%).

\section{Child health determinants on child HRQOL}

Most studies assess chronic health problems' influences on a child's HRQOL $[6,16,23]$, but few studies assessed the influence of acute illness. A study on determinants of HRQOL in Dutch school-age children's in the general population found that children who had acute health complaints showed lower scores of HRQOL [6]. Our study found that the best predictor of children's HRQOL was the presence of acute illness during the past month. In multivariate regression analysis, we consistently found that having an acute disease, such as upper respiratory symptoms and diarrhea, during the past month was associated with a lower score of the child's HRQOL from the self-reports and proxy-reports across all domains. During the past month, more than one-third of our children have cough or/and coryza, with or without fever. We excluded children who were hospitalized during the past last month. Our sample represented that upper respiratory tract symptoms are a prevalent child health problem in our setting. A most acute cough is due to an upper respiratory tract infection (URTI) [29]. Even though URTI is associated with low mortality, it significantly disturbs children's daily activities such as sleeping and eating and may cause school absences and parent work absences [30]. A previous study assessing the effect of acute cough on child HRQOL using the Parent-proxy Children's Acute Cough-specific QoL (PAC-QoL) Questionnaire found that children who suffered acute cough have lower HRQOL across all domains [31]. 
Table 3 Bivariate analysis of health-related quality of life's determinants based on child report

\begin{tabular}{|c|c|c|c|c|c|c|}
\hline Scale Description & $\begin{array}{l}\text { Total score } \\
\text { Mean (SD) }\end{array}$ & $\begin{array}{l}\text { Physical health } \\
\text { Mean (SD) }\end{array}$ & $\begin{array}{l}\text { Psychosocial health } \\
\text { Mean (SD) }\end{array}$ & $\begin{array}{l}\text { Emotional functioning } \\
\text { Mean (SD) }\end{array}$ & $\begin{array}{l}\text { Social Functioning } \\
\text { Mean (SD) }\end{array}$ & $\begin{array}{l}\text { School Functioning } \\
\text { Mean (SD) }\end{array}$ \\
\hline \multicolumn{7}{|l|}{ Age Group } \\
\hline $\begin{array}{l}\text { Children group (2-12Years) } \\
(n=300)\end{array}$ & $88.95(9.08)$ & $94.29(7.67)$ & $87.19(10.62)$ & $84.20(15.85)^{* *}$ & $92.38(11.69)^{*}$ & $85.00(14.54)$ \\
\hline $\begin{array}{l}\text { Adolescence group } \\
(13-18 \text { Years })(n=231)\end{array}$ & $89.71(8.70)$ & $94.17(7.65)$ & $88.21(9.87)$ & $86.47(14.71)$ & $94.11(9.64)$ & $83.55(12.71)$ \\
\hline \multicolumn{7}{|l|}{ Child gender } \\
\hline Male $(n=281)$ & $89.39(8.71)$ & $94.55(6.35)$ & $87.65(10.40)$ & $86.10(15.33)$ & $93.10(10.78)$ & $83.46(13.71)$ \\
\hline Female $(n=250)$ & $89.16(9.16)$ & $93.89(8.88)$ & $87.60(10.21)$ & $84.16(15.43)$ & $93.18(11.00)$ & $85.41(13.85)$ \\
\hline \multicolumn{7}{|l|}{ Number of children in the family } \\
\hline $2(n=348)$ & $89.87(8.17)^{*}$ & $94.63(7.04)$ & $88.29(9.54)^{*}$ & $86.05(14.33)$ & $93.38(9.87)$ & $85.31(13.05)^{*}$ \\
\hline$\geq 3(183)$ & $88.17(10.12)$ & $93.49(8.65)$ & $86.38(11.53)$ & $83.55(17.15)$ & $92.68(12.58)$ & $82.61(15.02)$ \\
\hline \multicolumn{7}{|c|}{ Position of the child in the family } \\
\hline 1st child $(n=231)$ & $90.31(7.48)^{*}$ & $94.80(6.56)$ & $88.82(8.71)^{*}$ & $86.13(14.36)$ & $94.33(8.72)^{*}$ & $85.84(12.22)^{*}$ \\
\hline 2nd or more $(n=300)$ & $88.12(10.00)$ & $93.67(8.29)$ & $86.27(11.58)$ & $83.89(16.59)$ & $91.55(13.00)$ & $83.38(14.68)$ \\
\hline \multicolumn{7}{|l|}{ Birth weight } \\
\hline$<2500 \mathrm{~g}(n=30)$ & $86.73(10.05)$ & $92.08(9.38)$ & $84.94(10.84)$ & $82.17(15.69)$ & $91.33(12.38)$ & $80.86(12.68)$ \\
\hline$\geq 2500 \mathrm{~g}(n=480)$ & $89.34(8.89)$ & $94.29(7.64)$ & $87.69(10.30)$ & $85.20(15.45)$ & $93.20(10.83)$ & $84.51(13.90)$ \\
\hline \multicolumn{7}{|l|}{ Mode of delivery } \\
\hline Normal $(n=455)$ & $89.44(8.90)$ & $94.48(7.49)$ & $87.76(10.33)$ & $85.27(15.55)$ & $93.18(10.97)$ & $84.65(13.83)$ \\
\hline $\mathrm{SC}(n=75)$ & $88.21(9.02)$ & $92.71(8.48)$ & $86.71(10.18)$ & $84.47(14.49)$ & $92.80(10.41)$ & $82.67(13.64)$ \\
\hline \multicolumn{7}{|c|}{ History of illness in the past one month } \\
\hline Yes $(n=237)$ & $87.50(9.22)^{* * *}$ & $92.76(8.09)^{* *}$ & $85.75(10.75)^{* * *}$ & $83.48(16.23)^{*}$ & $92.09(11.37)^{*}$ & $81.59(14.24)^{* *}$ \\
\hline No $(n=294)$ & $90.72(8.41)$ & $95.43(7.06)$ & $89.15(9.68)$ & $86.56(14.56)$ & $93.98(10.40)$ & $86.65(13.02)$ \\
\hline \multicolumn{7}{|l|}{ Location } \\
\hline Urban $(n=458)$ & $89.02(8.99)$ & $94.10(7.72)$ & $87.32(10.37)$ & $84.88(15.36)$ & $92.97(10.84)$ & $84.04(14.09)$ \\
\hline Rural $(n=73)$ & $90.95(8.31)$ & $95.08(7.22)$ & $89.58(9.72)$ & $87.12(15.52)$ & $94.18(11.09)$ & $86.69(11.51)$ \\
\hline \multicolumn{7}{|l|}{ Fathers' educational level } \\
\hline Basic education $(n=173)$ & $88.19(9.81)$ & $93.42(8.78)$ & $86.45(11.19)$ & $85.61(15.25)$ & $91.47(12.85)^{*}$ & $81.79(14.35)^{* *}$ \\
\hline Higher education ( $n=358)$ & $89.81(8.41)$ & $94.63(7.02)$ & $88.20(9.81)$ & $84.99(15.47)$ & $93.94(9.69)$ & $85.61(13.38)$ \\
\hline \multicolumn{7}{|l|}{ Mothers' educational level } \\
\hline Basic education ( $n=169$ ) & $89.17(9.05)$ & $94.12(8.28)$ & $87.56(10.24)$ & $86.33(14.43)$ & $92.04(12.08)$ & $83.62(14.34)$ \\
\hline Higher education $(n=362)$ & $89.33(8.87)$ & $94.29(7.35)$ & $87.66(10.34)$ & $84.65(15.81)$ & $93.65(10.24)$ & $84.73(13.56)$ \\
\hline \multicolumn{7}{|l|}{ Working parents } \\
\hline Both $(n=245)$ & $90.08(8.47)$ & $95.00(6.90)^{*}$ & $88.43(9.82)$ & $86.29(14.99)$ & $93.57(10.25)$ & $85.27(12.84)$ \\
\hline One or none $(n=286)$ & $88.60(9.24)$ & $93.59(8.20)$ & $86.95(10.67)$ & $84.25(15.69)$ & $92.76(11.38)$ & $83.63(14.56)$ \\
\hline \multicolumn{7}{|l|}{ Insurance } \\
\hline $\begin{array}{l}\text { Paid by government or have no } \\
\text { insurance }(n=317)\end{array}$ & $88.78(9.36)$ & $93.57(7.96)^{*}$ & $87.17(10.83)$ & $84.53(16.60)$ & $92.95(10.84)$ & $83.88(14.07)$ \\
\hline Self-funding $(n=214)$ & $90.03(8.17)$ & $95.22(7.07)$ & $88.32(9.45)$ & $86.17(13.39)$ & $93.41(10.94)$ & $85.14(13.40)$ \\
\hline
\end{tabular}

${ }^{*} p<0.05 * * 0<0.01 ; \mathrm{SD}$, standard deviation

Analysis using Independent -sample T-test

We found that perinatal factors, namely LBW and abnormal delivery, were associated with a lower the child's HRQOL based on proxy-reports. This result was similar to a review study assessing the impact of preterm and LBW on HRQOL of preschool- and schoolaged children, adolescents, and young adults. The review found that the history of prematurity and LBW lower the HRQOL at various age groups. The effect of LBW and gestational age is greatest during the younger period, but the effect extended into adulthood [32]. Our finding is quite essential since LBW is still a significant public health problem. In 2015, an estimated 20.5 million live births were LBW, 91\% from low-middle income countries, mainly southern Asia (48\%) and sub-Saharan Africa (24\%) [33]. The prevalence of LBW in our study population was 5.6\% (self-reported) and 6.0\% (proxy-reported), 
Table 4 Bivariate analysis of health-related quality of life's determinants based on proxy-report

\begin{tabular}{|c|c|c|c|c|c|c|}
\hline Variable & $\begin{array}{l}\text { Total score } \\
\text { Mean (SD) }\end{array}$ & $\begin{array}{l}\text { Physical Functioning } \\
\text { Mean (SD) }\end{array}$ & $\begin{array}{l}\text { Psychosocial Functioning } \\
\text { Mean (SD) }\end{array}$ & $\begin{array}{l}\text { Emotional Functioning } \\
\text { Mean (SD) }\end{array}$ & $\begin{array}{l}\text { Social Functioning } \\
\text { Mean (SD) }\end{array}$ & $\begin{array}{l}\text { School Functioning } \\
\text { Mean (SD) }\end{array}$ \\
\hline \multicolumn{7}{|l|}{ Age } \\
\hline $\begin{array}{l}\text { Children (2-12 Years) } \\
(n=396)\end{array}$ & $91.77(7.42)^{* * *}$ & $96.05(6.84)$ & $90.29(8.89)^{* *}$ & $87.50(12.90)^{* *}$ & $95.04(9.03)^{* *}$ & $88.34(12.68)^{*}$ \\
\hline $\begin{array}{l}\text { Adolescence } \\
(13-18 \text { Years })(n=237)\end{array}$ & $94.78(4.82)$ & $96.86(5.16)$ & $94.10(5.58)$ & $92.15(9.90)$ & $98.90(3.30)$ & $90.97(9.28)$ \\
\hline \multicolumn{7}{|l|}{ Child gender } \\
\hline Male $(n=328)$ & $92.86(6.57)$ & $96.78(5.00)$ & $91.50(7.88)$ & $89.18(12.27)$ & $96.89(7.12)$ & $88.29(12.18)^{*}$ \\
\hline Female $(n=305)$ & $92.94(6.90)$ & $95.89(7.38)$ & $91.94(8.18)$ & $89.31(11.88)$ & $96.05(8.16)$ & $90.46(10.78)$ \\
\hline \multicolumn{7}{|c|}{ Number of children in the family } \\
\hline$<=2(n=422)$ & $92.76(7.11)$ & $96.25(6.70)$ & $91.56(8.44)$ & $89.18(12.54)$ & $96.40(7.59)$ & $89.15(11.90)$ \\
\hline$>2(n=211)$ & $93.17(5.90)$ & $96.55(5.31)$ & $92.02(7.12)$ & $89.36(11.10)$ & $96.66(7.77)$ & $89.75(10.86)$ \\
\hline \multicolumn{7}{|c|}{ Child position in the family } \\
\hline 1st child $(n=270)$ & $92.92(6.97)$ & $96.28(6.14)$ & $91.77(8.22)$ & $89.07(12.80)$ & $96.70(7.43)$ & $89.60(10.88)$ \\
\hline 2 nd or more $(n=363)$ & $92.88(6.55)$ & $96.40(6.38)$ & $91.67(7.88)$ & $89.37(11.52)$ & $96.32(7.81)$ & $89.15(12.08)$ \\
\hline \multicolumn{7}{|l|}{ Birth weight } \\
\hline$<2500 \mathrm{~g}(n=38)$ & $90.49(8.55)^{*}$ & $94.74(6.70)$ & $89.09(10.44)^{*}$ & $83.82(17.02)^{* * *}$ & $95.00(9.72)$ & $87.96(11.94)$ \\
\hline$\geq 2500 \mathrm{~g}(n=574)$ & $93.02(6.56)$ & $96.39(6.32)$ & $91.86(7.77)$ & $89.53(11.65)$ & $96.59(7.43)$ & $89.44(11.45)$ \\
\hline \multicolumn{7}{|l|}{ Mode of delivery } \\
\hline Normal $(n=528)$ & $93.20(6.58)^{* *}$ & $96.49(6.48)$ & $92.10(7.70)^{* *}$ & $89.74(11.50)^{*}$ & $96.76(7.39)^{*}$ & $89.61(11.37)$ \\
\hline SC $(n=104)$ & $91.33(7.25)$ & $95.64(5.10)$ & $89.72(9.29)$ & $86.68(14.51)$ & $95.05(8.77)$ & $87.73(12.54)$ \\
\hline \multicolumn{7}{|c|}{ History of illness in the past one 1 month } \\
\hline Yes $(n=313)$ & $91.02(7.43)^{* *}$ & $94.95(7.34)^{* *}$ & $89.67(8.72)^{* *}$ & $86.44(13.27)^{* *}$ & $95.42(8.55)^{* *}$ & $87.01(12.59)^{* *}$ \\
\hline No $(n=320)$ & $94.73(5.36)$ & $97.72(4.63)$ & $93.71(6.71)$ & $91.98(10.07)$ & $97.53(6.49)$ & $91.57(10.02)$ \\
\hline \multicolumn{7}{|l|}{ Location } \\
\hline Urban $(n=549)$ & $92.84(6.81)$ & $96.37(6.39)$ & $91.63(8.10)$ & $89.14(11.97)$ & $96.47(7.82)$ & $89.29(11.67)$ \\
\hline Rural $(n=84)$ & $93.28(6.19)$ & $96.21(5.43)$ & $92.24(7.51)$ & $89.88(12.82)$ & $96.61(6.41)$ & $89.80(10.88)$ \\
\hline \multicolumn{7}{|c|}{ Fathers' educational level } \\
\hline $\begin{array}{l}\text { Basic education } \\
(n=195)\end{array}$ & $91.83(7.31)^{* *}$ & $95.66(7.40)$ & $90.55(8.78)^{*}$ & $87.90(13.36)$ & $96.08(8.74)$ & $87.35(12.04)^{* * *}$ \\
\hline $\begin{array}{l}\text { Higher education } \\
(n=438)\end{array}$ & $93.37(6.40)$ & $96.66(5.67)$ & $92.23(7.61)$ & $89.84(11.42)$ & $96.67(7.11)$ & $90.24(11.25)$ \\
\hline \multicolumn{7}{|c|}{ Mothers educational level } \\
\hline $\begin{array}{l}\text { Basic education } \\
(n=195)\end{array}$ & $93.47(6.05)$ & $96.27(7.44)$ & $92.56(7.08)$ & $90.31(11.03)$ & $97.15(6.73)$ & $89.65(10.99)$ \\
\hline $\begin{array}{l}\text { Higher education } \\
(\mathrm{n}=438)\end{array}$ & $92.64(7.00)$ & $96.39(5.68)$ & $91.33(8.39)$ & $88.77(12.50)$ & $96.19(8.01)$ & $89.22(11.81)$ \\
\hline \multicolumn{7}{|l|}{ Working parents } \\
\hline Both $(n=285)$ & $93.27(6.63)$ & $96.36(5.34)$ & $92.19(8.03)$ & $89.40(12.42)$ & $96.89(7.61)$ & $90.39(11.10)^{*}$ \\
\hline One or none $(n=348)$ & $92.59(6.80)$ & $96.35(6.95)$ & $91.32(8.00)$ & $89.11(11.80)$ & $96.15(7.68)$ & $88.49(11.88)$ \\
\hline \multicolumn{7}{|l|}{ Insurance } \\
\hline $\begin{array}{l}\text { Paid by government } \\
\text { or have no insurance } \\
(n=371)\end{array}$ & $92.42(6.84)^{*}$ & $96.04(6.06)$ & $91.16(8.07)^{*}$ & $88.91(11.98)$ & $96.15(7.95)$ & $88.37(11.37)^{*}$ \\
\hline Self- funding $(n=262)$ & $93.57(6.52)$ & $96.80(6.54)$ & $92.49(7.90)$ & $89.71(12.21)$ & $96.97(7.18)$ & $90.69(11.22)$ \\
\hline
\end{tabular}

${ }^{*} p<0.05{ }^{*} p<0.01$

Analysis using Independent -sample T-test, SD Standard deviation

similar to the prevalence of LBW reported by Indonesian Basic Health Research 2018, which was 6.2\% [9]. LBW has been identified as a risk of adverse outcomes other than infant mortality-morbidity, including impaired neurodevelopment outcome at school-age and non-communicable diseases later in life [10]. A systematic review and meta-analysis studies on the impact of LBW on South Asian children found that children born with LBW have significantly impaired cognitive and motor function [34]. Our study provides an additional 
Table 5 Multivariate analysis of HRQOL Total score: self-report and proxy report

\begin{tabular}{|c|c|c|c|c|}
\hline \multirow[t]{2}{*}{ Variable } & \multicolumn{2}{|c|}{$\begin{array}{l}\text { Self-report (total score) } \\
N=510\end{array}$} & \multicolumn{2}{|c|}{$\begin{array}{l}\text { Proxy report (total score) } \\
N=612\end{array}$} \\
\hline & Coefficient & $\mathrm{Cl} 95 \%$ & Coefficient & $\mathrm{Cl} 95 \%$ \\
\hline Age ( 2 to 12 years old $=$ Ref $)$ & & & $2.55^{* *}$ & 1.49 to 3.61 \\
\hline Number of children ( $2=$ Ref $)$ & $-1.78^{*}$ & -3.28 to -0.17 & & \\
\hline History of illness in the past 1 month (healthy= Ref) & $-2.98^{* *}$ & -4.52 to -1.45 & $-3.00^{* *}$ & -4.02 to -1.98 \\
\hline Birth weight $(>2.500 \mathrm{~g}=$ Ref $)$ & & & $-2.46^{*}$ & -4.54 to -0.37 \\
\hline Mode of delivery (vaginal delivery= Ref) & & & $-1.45^{*}$ & -2.80 to -0.09 \\
\hline Living area (urban = ref) & $2.91^{*}$ & 0.69 to 5.10 & & \\
\hline Fathers' educational level (higher level = Ref) & $-1.73^{*}$ & -3.38 to -0.08 & $-1.66^{*}$ & -2.75 to -0.56 \\
\hline \multirow[t]{2}{*}{ Insurance (self-funding = Ref) } & & & $-1.20^{*}$ & -2.22 to -0.19 \\
\hline & \multicolumn{2}{|c|}{ adjusted $R^{2} .060$} & adjusted $R^{2} .128$ & \\
\hline
\end{tabular}

${ }^{*} p<0.05 ;{ }^{* *} p<0.01$

$\mathrm{Cl}$ Confidence interval

value to use HRQOL assessment, a simple but valid and reliable tool, to detect the impact of perinatal problems on the whole aspect of health in the preschool to adolescence period. Our finding also emphasized the importance of preventing LBW.

\section{Strengths and limitations}

This study has some limitations. This study was a cross-sectional study; therefore, the results only support an association between determinant variables and HRQOL, not causality. In addition, other determinants like school environment were not assessed. Thus further research is needed. A study in urban schoolchildren found that children's perception of closeness to school personnel and the school environment and 'school connectedness' were significantly related to the HRQOL [25]. We excluded children who have been diagnosed with chronic health problems, mental and behavioral health problems. However, a cluster sampling approach using the Health and Demographic Surveillance System (HDSS) sample frame makes this study represent HRQOL of "healthy" children in the semi-urban city of Indonesia. Including acute health complaints and LBW, common health problems in developing countries, as determinants of children's HRQOL, support the importance of health promotion and prevention. Using both proxy-reports and selfreports is also the strength of the study. We found there was a fair to moderate agreement between selfreports and proxy-reports. Self-report is considered the standard for measuring HRQOL because it is more likely to represent internal health measures than proxy reporting accurately $[35,36]$. However, parent proxyreport should be considered as a secondary measure contributed to health-seeking behavior or health care usage [37].

\section{Conclusions}

Sociodemographic determinants of a child's HRQOL, acute health problems, and LBW were associated with lower HRQOL in the general pediatric population. In low- and middle-income countries where acute infections and LBW are still prevalent, its prevention and appropriate interventions should improve child health.

\section{Abbreviations}

HDSS: The Health and Demographic Surveillance System; HRQOL: healthrelated quality of life; ICC: Intra-Class Correlation; LBW: Low birth weight; PACQoL: Parent-proxy Children's Acute Cough-specific QoL; Peds QL ${ }^{\mathrm{TM}}$ : Pediatric Quality of life Inventory ${ }^{\text {TM}}$; SPSS: Statistical Package for the Social Sciences; URTI: Upper respiratory tract infection; WHO: World Health Organization.

\section{Acknowledgments}

We would like to thank the Sleman Health and Demographic Surveillance System (HDSS) team for their support in collecting the data.

\section{Authors' contributions}

MNS, BWI, NMR and AW share the responsibility to develop the study design. MNS, BWI and NMR were responsible in collecting the data. MNS, ZS and AW performed data analysis. MNS and ZS have drafted the manuscript. All authors have read and approved the final manuscript.

\section{Authors' information}

MNS is Associate Professor of Department of Child Health, Faculty of Medicine, Public Health and Nursing, Universitas Gadjah Mada (UGM)/ RSUP DR Sardjito, Yogyakarta, Indonesia.

BWI is a Pediatrician of Department of Child Health, Faculty of Medicine,

Public Health and Nursing, Universitas Gadjah Mada (UGM)/ RSUP DR Sardjito, Yogyakarta, Indonesia.

NMR and ZS are Medical Doctors of the Faculty of Medicine, Public Health and Nursing, Universitas Gadjah Mada (UGM), Yogyakarta, Indonesia.

AW is Assistant Professor of Department of Biostatistics, Epidemiology, and

Population Health, Faculty of Medicine, Public Health and Nursing, Universitas

Gadjah Mada (UGM), Yogyakarta, Indonesia. 


\section{Funding}

This research was funded by Universitas Gadjah Mada.

\section{Availability of data and materials}

The datasets that support the conclusions of this article are available by request to the corresponding author. We do not make participants' data publicly available due to data protection restrictions and participant confidentiality.

\section{Declarations}

\section{Ethics approval and consent to participate}

Ethical approval was obtained from the Medical and Health Research Ethics Committee of the Faculty of Medicine, Public Health and Nursing, Universitas Gadjah Mada, Yogyakarta, Indonesia.

Written informed consent was obtained from all parents/guardians of the children 2-18years, and assent of 11-18years old children.

All procedures were performed in accordance with relevant guidelines.

\section{Consent for publication}

Not Applicable.

\section{Competing interests}

We declared that all authors have no competing interests to declare.

\section{Author details}

'Department of Child Health, Faculty of Medicine, Public Health and Nursing, Universitas Gadjah Mada (UGM)/ RSUP DR Sardjito, Jalan Farmako Sekip Utara, Yogyakarta 55281, Indonesia. ${ }^{2}$ Faculty of Medicine, Public Health and Nursing, Universitas Gadjah Mada (UGM), Yogyakarta, Indonesia. ${ }^{3}$ Department of Biostatistics, Epidemiology, and Population Health, Faculty of Medicine, Public Health and Nursing, Universitas Gadjah Mada (UGM), Yogyakarta, Indonesia.

Received: 18 August 2021 Accepted: 15 February 2022

Published online: 22 February 2022

\section{References}

1. Solans M, Pane S, Estrada MD, Serra-Sutton V, Berra S, Herdman M, et al. Health-related quality of life measurement in children and adolescents: a systematic review of generic and disease-specific instruments. Value Heal. 2008;11:742-64.

2. Simon $A E$, Chan $K S$, Forrest CB. Assessment of children's health-related quality of life in the United States with a multidimensional index. Pediatrics. 2008:121:e118-26.

3. Varni JW, Burwinkle TM, Seid M, Skarr D. The PedsQL 4.0 as a pediatric population health measure: feasibility, reliability, and validity. Ambul Pediatr. 2003;3:329-41.

4. DeSalvo KB, Bloser N, Reynolds K, He J, Muntner P. Mortality prediction with a single general self-rated health question. A meta-analysis. J Gen Intern Med. 2006;21:267-75.

5. Ravens-Sieberer U, Herdman M, Devine J, Otto C, Bullinger M, Rose M, et al. The European KIDSCREEN approach to measure quality of life and well-being in children: development, current application, and future advances. Qual Life Res. 2014;23:791-803.

6. Houben-van Herten M, Bai G, Hafkamp E, Landgraf JM, Raat H. Determinants of health-related quality of life in school-aged children: a general population study in the Netherlands. Plos One. 2015;10:e0125083.

7. Waters E, Davis E, Nicolas C, Wake M, Lo SK. The impact of childhood conditions and concurrent morbidities on child health and well-being. Child Care Health Dev. 2008;34:418-29.

8. Wilkins AJ, O'Callaghan MJ, Najman JM, Bor W, Williams GM, Shuttlewood G. Early childhood factors influencing health-related quality of life in adolescents at 13 years. J Paediatr Child Health. 2004;40:102-9.

9. Agency of Health Research and Development (Indonesia). Indonesia Basic Health Research (RISKESDAS). 2018. http://ghdx.healthdata.org/ record/indonesia-basic-health-research-2018. Accessed 16 May 2021.
10. World Health Organization. WHA global nutrition targets 2025: low birth weight policy brief. 2014. https://apps.who.int/iris/bitstream/handle/10665/ 149020/WHO_NMH_NHD_14.5_eng.pdf?ua=1. Accessed 18 May 2021.

11. Dewi FST, Choiriyyah I, Indriyani C, Wahab A, Lazuardi L, Nugroho A, et al. Designing and collecting data for a longitudinal study: the Sleman health and demographic surveillance system (HDSS). Scand J Public Health. 2018:46:704-10.

12. Sitaresmi MN, Mostert S, Gundy CM, Sutaryo, AJP V. Health-related quality of life assessment in Indonesian childhood acute lymphoblastic leukemia. Health Qual Life Outcomes. 2008;6:1-8.

13. Varni SM, Kurtin P. PedsQL ${ }^{\mathrm{TM}} 4$. 0: reliability and validity of the pediatric quality of life inventory version 4.0 generic core scales in healthy and patient populations. Med Care. 2001;39:800-12.

14. Varni JW. PedsQL ${ }^{\mathrm{TM}}$ administration guidelines; 1998. p. 1-2. https://www. pedsql.org/about_pedsql.html. Accessed 6 Dec 2021.

15. Rajmil L, López AR, López-Aguilà S, Alonso J. Parent-child agreement on health-related quality of life (HRQOL): a longitudinal study. Health Qual Life Outcomes. 2013;11:1-10.

16. Desai AD, Zhou C, Stanford S, Haaland W, Varni JW, Mangione-Smith $\mathrm{RM}$. Validity and responsiveness of the pediatric quality of life inventory (PedsQL) 4.0 generic core scales in the pediatric inpatient setting. JAMA Pediatr. 2014;168:1114-21.

17. Raj M, Sudhakar A, Roy R, Champaneri B, Joy TM, Kumar RK. Health-related quality of life in Indian children: a community-based cross-sectional survey. Indian J Med Res. 2017;145:521-9.

18. The World Health Organization Quality of Life assessment (WHOQOL). Position paper from the World Health Organization. Soc Sci Med. 1995;41:1403-9.

19. Jaafar JL, Utoro V, Yunanto KT, Chusniyah T. Malaysian and Indonesian adolescents' resiliency and relationships with gratitude and happiness. 2019. http://fppsi.um.ac.id/wp-content/uploads/2019/03/Malaysian-andIndonesian-Adolescents.pdf. Accessed 6 Dec 2021.

20. The Varkey Foundation. Generation Z: global citizenship survey: The Varkey Foundation; 2017. https://www.varkeyfoundation.org/media/4487/ global-young-people-report-single-pages-new.pdf. Accessed 6 Dec 2021.

21. The Varkey Foundation. Global young people report Indonesia. 2017. https://www.varkeyfoundation.org/media/2776/global-young-peoplereport-indonesia.pdf. Accessed 6 Dec 2021.

22. Sarria EE, Mundstock E, Machado DG, Mocelin HT, Fischer GB, Furlan SP, et al. Health-related quality of life in patients with bronchiolitis obliterans. J Pediatr (Rio J). 2018;94:374-9.

23. Didsbury MS, Kim S, Medway MM, Tong A, McTaggart SJ, Walker AM, et al. Socio-economic status and quality of life in children with chronic disease: a systematic review. J Paediatr Child Health. 2016;52:1062-9.

24. Fachrunnisa R. Education of Indonesian girls: the outlook of discrimination, rights, and the impact on society. KnE Soc Sci. 2020;2020:349-59.

25. Mansour ME, Kotagal U, Rose B, Ho M, Brewer D, Roy-chaudhury A, et al. Health-related quality of life in urban elementary school children. Pediatrics. 2003;111(6 Pt 1):1372-81.

26. OECD. Social protection system review of Indonesia: OECD Development Pathways, OECD; 2019. https://www.oecd.org/social/inclusivesocietiesan ddevelopment/SPSR_Indonesia_ebook.pdf. Accessed 18 May 2021.

27. Institute of Medicine (US) Committee on the Consequences of Uninsurance. Care without Coverage: Too Little, Too Late. Washington (DC): National Academies Press (US); 2002.

28. Meyer M, Oberhoffer R, Hock J, Giegerich T, Müller J. Health-related quality of life in children and adolescents: current normative data, determinants and reliability on proxy-report. J Paediatr Child Health. 2016;52:628-31.

29. Marseglia GL, Manti S, Chiappini E, Brambilla I, Caffarelli C, Calvani M, et al. Acute cough in children and adolescents: a systematic review and a practical algorithm by the Italian Society of Pediatric Allergy and Immunology. Allergol Immunopathol (Madr). 2021;49:155-69.

30. Schot MJC, Dekker ARJ, Van Werkhoven CH, Van Der Velden AW, Cals JWL, Broekhuizen BDL, et al. Burden of disease in children with respiratory tract infections in primary care: diary-based cohort study. Fam Pract. 2019;36:723-9.

31. Aldayel A, Aljabri M, Alobaidi A, Hakami N, Ghasib F, Mujallid M, et al. Quality of life of children with acute cough: a cross-sectional study. Int J Med Dev Ctries. 2020;4 October:2149-52. 
32. Zwicker JG, Harris SR. Quality of life of formerly preterm and very low birth weight infants from preschool age to adulthood: a systematic review. Pediatrics. 2008;121:e366-76.

33. Blencowe H, Krasevec J, de Onis M, Black RE, An X, Stevens GA, et al. National, regional, and worldwide estimates of low birthweight in 2015, with trends from 2000: a systematic analysis. Lancet Glob Heal. 2019;7:e849-60.

34. Upadhyay RP, Naik G, Choudhary TS, Chowdhury R, Taneja S, Bhandari N, et al. Cognitive and motor outcomes in children born low birth weight: a systematic review and meta-analysis of studies from South Asia. BMC Pediatr. 2019;19:1-15.

35. Nolan LB. An exploration of proxy- and self-reported adolescent health in low-resource settings. Surv Res Methods. 2016;10:65-83.

36. Cummins RA. Proxy responding for subjective well-being: a review. Int Rev Res Ment Retard. 2002;25:183-207.

37. Varni JW, Limbers CA, Burwinkle TM. Parent proxy-report of their children's health-related quality of life: an analysis of 13,878 parents' reliability and validity across age subgroups using the PedsQL ${ }^{\mathrm{TM}} 4.0$ generic core scales. Health Qual Life Outcomes. 2007;5:2.

\section{Publisher's Note}

Springer Nature remains neutral with regard to jurisdictional claims in published maps and institutional affiliations.

- fast, convenient online submission

- thorough peer review by experienced researchers in your field

- rapid publication on acceptance

- support for research data, including large and complex data types

- gold Open Access which fosters wider collaboration and increased citations

- maximum visibility for your research: over $100 \mathrm{M}$ website views per year

At BMC, research is always in progress.

Learn more biomedcentral.com/submissions 